\title{
The impact of the COVID-19 pandemic on lifestyle behaviors in children and adolescents: an international overview
}

\author{
S. Scapaticci' , C. R. Neri ${ }^{1}$, G. L. Marseglia ${ }^{2}$, A. Staiano ${ }^{3}$, F. Chiarelli ${ }^{1 *}$ and E. Verduci ${ }^{4}$
}

\begin{abstract}
The adverse effects of Severe Acute Respiratory Syndrome Coronavirus 2 (SARS-CoV-2) are not limited to the related infectious disease. In children and adolescents, serious risks due to the coronavirus disease 2019 (COVID-19) pandemic are also related to its indirect effects. These include an unbalanced diet with an increased risk of weight excess or nutritional deficiencies, increased sedentary lifestyle, lack of schooling, social isolation, and impaired mental health.

Pediatricians should be aware of the side effects of the COVID-19 pandemic on children's diet, physical mental health and advise the families according to their nutritional needs and financial resources. Moreover, the lack of a targeted therapy able to offer protection against the deleterious effects of SARS-CoV-2 infection should require a greater effort by scientific societies to find a more effective prevention strategy. In this context, much interest should be given to nutritional support, able to contrast malnutrition and to stimulate the immune system.
\end{abstract}

Keywords: COVID-19 and children, SARS-CoV-2 infection and children, COVID-19 and nutrition, COVID-19 and lifestyle

\section{Background}

Starting in 2020, the COVID-19 pandemic, whose causative agent is SARS-CoV-2, has represented the primary global issue influencing lifestyle behaviors of people worldwide. Wuhan, in China, has been the first city in which the SARS-CoV-2 virus has been detected, but soon the virus dissemination spread all over the world forcing World Health Organization (WHO) to declare the global pandemic state on 11th March 2020 [1]. SARS-CoV-2 is a pathogen with a particular tropism for respiratory tract epithelial cells leading to respiratory clinical pictures of various degrees of gravity, ranging from mild form characterized by cough, sore throat, and rhinitis to respiratory failure and acute respiratory distress (ARDS), secondary to virus colonization of the

\footnotetext{
*Correspondence: chiarelli@unich.it

${ }^{1}$ Department of Paediatrics, University of Chieti-Pescara, Chieti, Italy

Full list of author information is available at the end of the article
}

most distal region of the bronchial tree [2]. Respiratory symptoms frequently are associated with fever, headache, asthenia, diarrhea, vomiting, anosmia and, ageusia [3]. In severe cases of COVID-19, the viral dissemination into the bloodstream may determine secondary involvement of kidneys, esophagus, bladder, ileum, heart tissues, and central nervous system [4].

COVID-19 affects the pediatric population with a prevalence of $5 \%$ of all the cases diagnosed worldwide, with predominance for children and adolescents exposed to infected family members $[5,6]$. Accordingly to data collected from different reports of the Literature, the median age at the diagnosis is of 6.6years [7]. A recent meta-analysis reported a higher prevalence in female cases than males (56\%) [2]. Fortunately, children seem to have a milder clinical course of COVID-19 than adults [1]. A large-scale study conducted on more than 2000 pediatric patients in China, observed that the rate of asymptomatic children with confirmed/suspected original author(s) and the source, provide a link to the Creative Commons licence, and indicate if changes were made. The images or other third party material in this article are included in the article's Creative Commons licence, unless indicated otherwise in a credit line to the material. If material is not included in the article's Creative Commons licence and your intended use is not permitted by statutory regulation or exceeds the permitted use, you will need to obtain permission directly from the copyright holder. To view a copy of this licence, visit http://creativecommons.org/licenses/by/4.0/. The Creative Commons Public Domain Dedication waiver (http://creativeco mmons.org/publicdomain/zero/1.0/) applies to the data made available in this article, unless otherwise stated in a credit line to the data. 
COVID-19 was $94.1 \%$ of whose $4.4 \%$ were completely asymptomatic while approximately $6 \%$ developed severe disease [5]. This may explain the observed low mortality of $<1 \%$ of all deaths [8].

The most frequent symptoms in the pediatric patients affected with COVID-19 are fever (57\% with CI 49.764\%) and cough (44.1 with CI 38.3-50.2\%) [9]. However, influenza-like symptoms (headache, fatigue, rash, myalgia, dyspnea, rhinorrhea, nasal congestion, sore throat, nausea, vomiting, and abdominal pain) often coexist, making difficult to formulate a differential diagnosis $[6$, 10]. In addition, olfactory and gustatory abnormalities (typical of adult cases of SARS-CoV-2 infection) are rare in pediatric populations $[11,12]$. The reasons why children and adolescents with SARS-CoV-2 infection have a milder disease course than adults are not yet clear. It has been suggested that biological factors in children, such as an immature immune system, could play a role to offer protection against damaging effects secondary to viral infection and abnormal immune system activation [13]. Moreover, differences in angiotensin-converting enzyme 2 (ACE2) expression may explain why SARS$\mathrm{CoV}-2$ infection is milder among children than adults as it represents the main gate for infection. The interaction between the SARS-CoV-2 envelope-anchored spike protein and ACE2 allows the entry of the virus into the type II alveolar cells of the lung. As a protective factor against SARS-CoV-2 infection, children seem to have a different ACE2 configuration, concentration, or binding capacity or a less harmful alveolar epithelial cell response to ACE2 when compared with adults [14].

However, the possibility to evolve towards severe disease stages is rare, but not impossible. In a pediatric case series of children with COVID-19, 30.8\% presented dyspnea requiring ventilator support with oxygen, while $23.1 \%$ developed organ dysfunction, in the form of Multisystem Inflammatory Syndrome in Children (MIS-C), requiring intensive care unit (ICU) [15]. Recent epidemiological data reported the possibility to detect ground-glass opacities, a typical radiological finding of adult patients affected with COVID-19, in 35.5\% (CI 28.9-42.7\%) of all diagnosed pediatric cases, while the hospitalization rate seems to settle to $96.3 \%$ (CI 92.4-98.2\%) of which $10.8 \%$ (CI 4.2-25.3\%) with ICU admissions, and a rate of mortality of $2.4 \%$ (CI $1.7-3.4 \%$ ) [16].

Given the high prevalence of asymptomatic cases and the lack of a single consensus about the screening procedure, the possibility to detect a large number of pediatric subjects affected with SARS-CoV-2 infection is reduced [17]. Add to this, the rate of newly reported COVID-19 cases depends on the local testing strategy, laboratory capacity, and the effectiveness of surveillance systems [18].
As a particular feature, pediatric patients with mild/ moderate COVID-19 are likely to have higher nasal viral loads responsible for a silent spread in communities like schools, children's playrooms [19] and mostly it might offer the chance to infect grandparents and other family members who are at risk to develop a severe course of the disease. However, their role in transmitting SARS-CoV-2 infection could be underestimated.

Given the high rate of SARS-CoV-2 contagiousness and rapid diffusion, since March 2020, there have been introduced multiple restrictions on human activities and physical interactions worldwide to prevent the spread of the virus, which forced people to stay at home influencing their food habits and lifestyles with potentially negative health consequences [20].

One of the first decisions taken by states and local governments was to declare primary and secondary school closures. For adolescents, physical activity (PA) is closely related to school-based activities; pre-COVID-19 pandemic, schools provided between 90 and $150 \mathrm{~min}$ per week of PA through physical education and recess. The same closure also affected other activities, such as gyms and various fitness and recreational centers. As a result, during pandemic children typically were engaged in lower levels of PA, fundamental to maintain mental and physical health, and adopted a more sedentary lifestyle as compared to school days [21].

Such necessary restrictions also determined changes in eating habits interfering with the maintenance of a healthy and balanced diet. As a consequence, a greater rate of obesity and nutritional deficiencies has been documented during COVID-19 pandemic [22]. Changes in the nutritional patterns during the pandemic were also due to the financial struggles related to COVID-19 which forced a large number of families to ration food and make cheaper and unhealthy food choices. Furthermore, school closures prevented children belonging to poor families to receive free school lunches and healthy snacks exposing them to food insecurity [23].

This overview aims to describe the consequences of the COVID-19 pandemic on children and adolescents' lifestyles analyzing the data that has emerged in international literature over the past months.

\section{Methods}

We reviewed the literature analyzing the changes in health-related quality of life of the pediatric population pre and during COVID-19 pandemic to understand the impact of this global health issue on children and adolescents' lifestyle behaviors. We present results from systematic reviews and meta-analysis, randomized controlled trials (RCTs) and large observational studies published from 2020 so far reporting data about the following 
issues: changes in eating habits during COVID-19 pandemic; the reduced rate of physical activity in children secondary to schools closures and the limited human activities; the increased rate of obesity among children and adolescents consequent to the sedentary lifestyle and bad eating habits; micronutrients deficiencies related to unhealthy diet; the mental health consequences of quarantine on adolescents leading to sleep disturbances; prevention strategies in terms of nutritional and psychological support among children and adolescents. PubMed has been used as search engine using as key words: COVID-19 and children, SARS-CoV-2 infection and children, COVID-19 and nutrition, COVID-19 and lifestyle.

\section{The impact of quarantine on children and adolescents}

To contain the spread of COVID-19, starting March 2020 states and local governments established restrictions that limited human contact with strong implications in the health, social, and economic fields. In Italy, citizens had to practice social distance maintaining at least $2 \mathrm{~m}$ between individuals and avoid social meetings, physical contact, crowded places, and nonessential activities [24]. School closures were also necessary to contain the extension of COVID-19 and forced children and adolescents to stay at home during the lockdown practicing the socalled "distance learning" [20].

The consequences of these confinement measures led to increased sedentary behaviors, with a greater risk of developing or worsening chronic health conditions both on a physical and a mental level even for the young population [25].

Although children and adolescents seem to be less directly affected by the virus, they are struggling against the collateral damages of the COVID-19 pandemic, including inadequate diet, impaired mental health, social isolation, addiction to screens, and lack of schooling and sport activities [26].

\section{Changes in food habits}

A longitudinal observational study, conducted in Italy, documented negative changes in diet, sleep, and lifestyle behaviors in children and adolescents with obesity during a 3 weeks of home confinement. The study included 41 obese children aged $6-18$ years and showed that consumption of potato chip, red meat and sugary drinks increased significantly during the lockdown $(P$-value range: 0.005 to $<0.001$ ) [27].

Another Italian survey conducted from the 5 th to the 24th of April 2020, which included 3533 individuals aged between 12 and 86 years, showed that the population group aged between 12 and 17 years have an increased intake of junk food and lower adherence to the Mediterranean diet when compared to the group aged 18-30. In this study population, a higher BMI, as well as a lower age, were associated with increased consumption of packaged sweets and baked products, sweet beverages, savory snacks and dressing sauces [28].

The same results came from a study conducted among 820 adolescents (10-19years) from Spain, Italy, Brazil, Colombia, and Chile. The reported percentage of adolescents that consumed sweet food every day increased from 14 to $20.7 \%$ during confinement. Similarly, the increase of adolescents who consumed fried foods $4-7$ days per week, went from $7.4,3.7,1.8$ and $2.1 \%$ to $8.8,3.8,2.2$ and $2.9 \%$ during quarantine [29].

A retrospective cohort study conducted at the Growth Clinic of Seoul St. Mary's Hospital among school-aged children between 4 and 14years investigated changes in anthropometric and metabolic parameters during 6 months period of social distancing and school closure due to the COVID-19 pandemic. Data showed an increase in BMI z-scores of 0.219 (95\% confidence interval $[C I], 0.167-0.271 ; P<0.001)$ in the COVID-19 period compared to the 1-year period prior to school closure. Likewise, the proportion of overweight or obesity went from $23.9 \%$ in the pre-COVID-19 period to $31.4 \%$ in the COVID-19 period [30].

Additionally, $41.7 \%$ of the adolescents in Palestine reported weight gain and $50 \%$ stated that their food intake increased compared to before the lockdown. Regarding nutrition intake, 31.5\% consumed larger quantities of sugar-added drinks (soda, processed juices, etc.), $36.7 \%$ reported an increase in fried foods intake, while $46.5 \%$ declared a greater consumption of sweets and sugar-added food in comparison to before the lockdown [31].

These results confirm that the confinement led to unfavorable eating behaviors and frequent snacking in adolescents considering that food has the power to comfort and support people in stressful conditions [32]. Particularly, foods rich in sugars have a positive effect on mood and reduce stress due to serotonin production [33]. Furthermore, chronic stress activates the hypothalamus-pituitary-adrenal axis, which controls the eventual release of cortisol. Cortisol stimulates highly palatable food intake (e.g., processed foods high in fat and sugar), leading to excessive caloric intake [34].

\section{Physical activities}

Unfortunately, restrictions on human contacts that limit participation to outdoor activities are inevitably disrupting the daily routine of millions of people, including children and adolescents, making it difficult to practice regular physical activity (PA) and exercise [25]. 
Results that came from various studies show that the current measures are not adequate to maintain sufficient levels of PA at home.

In this regard, a Canadian study provided evidence of collateral consequences of the COVID-19 outbreak in children and youth, demonstrating that only $3.6 \%$ of kids (5-11 years) and only $2.6 \%$ of adolescents ( $12-17$ years) were practicing $60 \mathrm{~min}$ of moderate-vigorous PA/day during the COVID-19 pandemic [35].

Similarly, data derived from an experimental longitudinal study conducted among 2426 children and adolescents (6-17years) in five schools in Shanghai, showed a drastic decrease in the median time spent in PA which went from $540 \mathrm{~min} /$ week (before the pandemic) to $105 \mathrm{~min} /$ week (during the pandemic). In conclusion, during the pandemic, the prevalence of physically inactive students increased from 21.3 to $65.6 \%$ [36].

Also in Italy children between 6 and 18 years of age with obesity reduced PA to $2.3( \pm 4.6 \mathrm{SD})$ hours/week $(P=0.003)$ while screen time increased to $4.8( \pm 2.4 \mathrm{SD})$ hours/day $(P<0.001)$ [27].

Each session of moderate-intensity PA promotes the antipathogen activity of macrophages stimulating the recirculation of immune system cells, immunoglobins and anti-inflammatory cytokines in the blood. Thereby, PA can reduce the influx of inflammatory cells in the lungs counteracting pathogen load and attenuating symptomatology of infectious diseases [37].

The downside of the drastic decrease in PA during lockdown, besides its correlation with loss of muscular and cardio-respiratory fitness and weight gain, is that children and adolescents are also experiencing increased levels of anxiety and depression highlighting the positive mental health effects of engaging in physical activity and limiting recreational screen time, especially during stressful periods [36]. On the other hand, increased PA in childhood and adolescence is associated with decreased depressive symptoms [38].

\section{Covibesity}

Such food habits, in association with a reduction of physical activities, reflect in an increased risk of obesity in children and adolescents as pointed out by the newly developed term "covibesity" which has been introduced to portray the aggravation in obesity rates due to the lockdown imposed during the pandemic [39].

According to the European Society for Clinical Nutrition and Metabolism (ESPEN), the obesity condition is also related to the severity of COVID-19. It has emerged as one of the most prominent risk factors increasing the disease mortality even in childhood [40]. The pathophysiological process that compromises the functioning of organs and systems in obese individuals includes excessive adipose tissue, deficit in lean mass, insulin resistance, dyslipidemia, arterial hypertension, nonalcoholic steatohepatitis, micronutrients deficiencies, increased oxidative stress, hyperuricemia along with modification of the intestinal microbiota (dysbiosis). These factors lead to chronic subclinical inflammation, impaired immune response, and cardiorespiratory diseases which are the three main risk factors that link obesity to COVID-19. Additionally, obese children are more exposed to the risk of developing severe complications of COVID-19 such as bacterial pneumonia and thromboembolism [41].

Children with obesity have also an increased risk for ventilatory assistance as proved by the fact that in the Children's Hospital in New York obesity was the most important risk factor for the necessity of respiratory support among 50 pediatric cases of COVID-19 [42].

A recent meta-analysis showed that children who were overweight or obese accounted for $50 \%(n=136$ of 268) of children with MIS-C adding a further possible risk associated with this condition [43].

Interestingly, it has been postulated that childhood obesity rates might increase in proportion to the number of months that schools remain closed: data from the USA estimated that until December 20201.27 million new childhood obesity cases were recorded if schools did not reopen [44].

Among the collateral damages of the virus, there are also the economic aspects and their implications in dietary changes considering that many meals for lowincome children are provided by schools and childcare centers paying attention to the maintenance of a balanced diet. In fact, because of wide-spread school closures, food insecurity, defined as "having inadequate access to sufficient, safe, and nutritious food to meet dietary needs and food preferences for an active and healthy lifestyle", had been magnified among low-income children [34, 45].

\section{Malnutrition and nutritional deficiencies}

Changes in food habits and eating patterns during COVID-19 pandemic, switched to an unbalanced diet, are responsible for an increased risk of obesity and nutritional deficiencies. Infancy and early childhood are key periods for individual growth. Therefore, an unhealthy diet might have a damaging effect on corporeal and weight-for-height development. In addition, since during infancy strongly rooted eating habits are acquired, inadequate nutrition at the pediatric age could have life-long repercussions [46].

Social and income inequalities represent a major determinant for poor outcomes in both developed and developing countries, and COVID-19 pandemic crisis has even more marked these differences. In the middle-and 
high-income countries the unhealthy diet has favored a high energy density diet and consequently an increased risk of obesity. In contrast, in low-income countries where underweight and overweight could coexist, the balance has moved towards undernutrition [47]. Malnutrition increases morbidity and mortality during infections and causes a significant economic impact on the health care systems [47]. Simultaneously, infections increase the need for several nutrients necessary to maintain bodily integrity and to support immune system activity [48]. In fact, it is well-recognized that nutrition has an important role in modulating the immune response. In this regard, Calder et al. have highlighted the importance of optimal nutritional status as a protective factor against viral infections [49]. In applying these considerations to the current COVID-19 pandemic, $\mathrm{Wu}$ and colleagues have underlined how a nutritional intervention might reduce damages to the lung of patients affected with SARS-CoV-2 [50].

Several vitamins and trace elements, belonging to the group of micronutrients, have been studied in association with the normal functioning of the immune system [51]. Micronutrients regulate enzyme cellular activities, redox processes, and gene expression: consequently, a deficit of one or more of them could partly explain the increased susceptibility to infections and at the same time might offer a potential cue for new preventive and therapeutical approaches based on their supplementations.

Vitamin A has been studied for its important function in regulating immune function, in both cellular and humoral immune responses [52]. Studies on infants have shown that Vitamin A supplementation leads to increased production of antibodies after vaccines, like measles [52], anti-rabies vaccination (2.1 times) [53] and influenza virus vaccination, also in children [54]. In order to reduce mortality and risk of complications from pneumonia, croup, and ocular problems it is recommended to correct the low or depleted retinol concentrations resulting from measles infection. This can have some interesting implications considering that severe COVID-19 infection has measles-like manifestations which include fever, cough, and pneumonia but, to date, there is still little evidence to support a beneficial effect of vitamin A supplementation on respiratory infections. However, WHO recommends vitamin A as part of the standard treatment package for all children with acute measles [55].

Similarly, supplementation with vitamin C (100$200 \mathrm{mg} /$ day) is known to support respiratory defense mechanisms preventing viral infection which makes it a target of interest in COVID-19 management [56]. In fact, placebo-controlled trials focused on the way to prevent or treat the common cold with oral doses of vitamin C of $200 \mathrm{mg} /$ day demonstrate that the duration of cold episodes is significantly reduced in both children and adults during prophylaxis with an average reduction of $14 \%$ in symptom days for children, while in adults the reduction was $8 \%$ [57]. Because of its capacity to reduce excessive activation of the immune response, adequate levels of vitamin $\mathrm{C}$ are also proved to increase the survival rate of COVID-19 patients. Interacting with both the innate and adaptive immune system, vitamin $C$ encourages antiviral cytokines and free radical formation, hindering viral replication and counteracting abnormal inflammatory responses and hyperactivation of immune cells [58].

Vitamin $C$ modulates the levels of pro-inflammatory cytokines such as TNF- $\alpha$ and promotes the release of interleukin-10 (IL-10) which limits IL-6 levels by a negative feedback mechanism and controls inflammation, critical in COVID-19. In particular, clinical studies suggest that the intake of $1 \mathrm{~g} /$ day of vitamin $C$ increases IL-10 secretion by peripheral blood mononuclear cells [59].

Vitamin $\mathbf{D}$ has been largely studied as a possible protective factor against acute viral respiratory infections suggesting a preventive or even a therapeutic role in COVID-19 [32, 60]. Although vitamin D is usually known for its role in the maintenance of bone health and calcium-phosphorus metabolism, many other functions of this hormone have been recently discovered. In fact, Vitamin D can interact both with the innate immune system, by activating Toll-like receptors (TLRs) or increasing the levels of cathelicidins and $\beta$-defensins, and the adaptive immune system, by reducing immunoglobulin and proinflammatory cytokines production, thus modulating $\mathrm{T}$ cells function and reducing lung inflammation [61-63]. Through human cathelicidin peptide LL37, it also exerts a potent antiviral effect on a variety of viruses, such as HIV-1, influenza viruses, HSV1-2, rhinovirus, and HCV [64-67]. However, it is not known the adequate supplementation regimen to adopt in order to obtain serum levels of vitamin $D$ that guarantee its immunomodulatory role. By the way, serum levels of vitamin D near $20 \mathrm{ng} / \mathrm{mL}$ and $50 \mathrm{ng} / \mathrm{mL}$ should be enough [67].

The clinical importance of vitamin $\mathrm{D}$ within the immune system has been remarkably confirmed during the current pandemic as various metanalysis showed that its deficiency increases the risk of severe COVID-19, hospitalization with COVID-19 and mortality from COVID19 in adults [68].

Similarly, a study that included 40 patients with COVID-19 aged between 3 months and 18years and 45 healthy matched control showed that children with COVID-19 had significantly lower vitamin D levels $13.14 \mu \mathrm{g} / \mathrm{L}(4.19-69.28)$ in comparison to the controls $34.81(3.8-77.42) \mu \mathrm{g} / \mathrm{L}(p<.001)$ with fever significantly 
higher in COVID- 19 patients who had deficient and insufficient vitamin D levels than in patients who had sufficient vitamin D levels $(p=.038)$ [69].Despite its correlation with the risk of developing COVID-19 in children, because of the deregulated eating pattern established during pandemic, a significant decrease in 25OHD $(18.9 \mathrm{mg} / \mathrm{dL}$ vs. $23.8 \mathrm{mg} / \mathrm{dL}, P<0.001)$ was observed among children during the COVID-19 period compared to pre-COVID-19 period pointing out the importance of a vitamin $\mathrm{D}$ supplementation during the current pandemic [30].

Vitamin $\mathbf{E}$ is another fat-soluble vitamin with potent antioxidant action, able to reduce ROS damaging effects [51]. Also in this case, several studies suggested a possible role for vitamin $\mathrm{E}$ in modulating immune responses with unknown mechanisms [52]. Moreover, it acts synergistically with selenium in preventing virus-inducing myocardial damage [70], including the one from SARS-CoV-2 [71]. Based on these considerations, vitamin E supplementation might be an option to contain long-term damages of COVID-19. However, in view of the few data available to date, this vitamin is not used as a preventive strategy for viral infections.

The iron role is controversial. It is a trace element influencing the number and activity of T CD4 circulating cells, facilitating a higher Th1 subtype response than Th2 [72-74]. In fact, it has been reported a predominance of allergy in children and adolescents with iron deficiency and an elevated risk to develop atopic diseases in children whose mothers have had low iron levels during pregnancy $[75,76]$. However, this element is also a source of nourishment for many pathogens [77]. Not surprisingly anemia is one of the clinical and laboratory during an inflammatory chronic process aimed to reduce the substrates for pathogens [78]. Therefore, it is necessary for a good iron plasmatic homeostasis to balance its pro-inflammatory and anti-inflammatory effects. A preliminary evaluation of serum iron, ferritin and transferrin should be made before considering any possible supplementation.

In contrast, the use of zinc compounds might be an adjunct therapy in COVID-19 treatment. Beyond its ability to modulate the immune system, zinc can improve barrier functions enhancing cilia's morphology and increasing its length and beating frequency [79]. Moreover, it promotes antiviral and antioxidants actions that offer protection to the respiratory epithelial lining. For these reasons, an uptake of up to $40 \mathrm{mg}$ per day of zinc is recommended for adults to reduce the potential threat of the COVID-19 pandemic, resulting from the rise in the host resistance to viral infections [80]. Indeed, a study conducted in Thailand among children aged between 2 and 60 months found that acute lower respiratory tract infections solved faster in the ones who received zinc supplementation (median (IQR): 3 (2-4) days and 4 (3-5) days, respectively; $P=0.008$ ), and that their hospital stay was shorter (mean (SD): 3.8 (1.3) days and 6.1 (3.2) days) than the placebo group [81]. Based on these considerations, it could be assumed that zinc supplementation may be useful also for children.

Likewise, selenium $(\mathrm{Se})$ is an essential trace element relevant for a well-balanced immune response [82]. In fact, a cross-sectional study of patients affected by COVID-19 conducted in Germany demonstrated that Se status analysis in COVID patients provides diagnostic information for a better prediction of the disease course and of the risks associated. A Se status below $<45.7 \mu \mathrm{g} / \mathrm{L}$ was documented in $43.4 \%$ of COVID samples in contrast with the levels of selenium found in samples from surviving COVID patients which were significantly higher in comparison to non-survivors (Se; $53.3 \pm 16.2$ vs. $40.8 \pm 8.1 \mu \mathrm{g} / \mathrm{L}$ ) suggesting a possible role of this trace element in facing the viral infection. In light of these results, Se supplementation could represent an adjuvant therapy in COVID-19 patients [83]. Furthermore, an interesting correlation between COVID-19 cure rate and city population selenium status based on hair selenium concentration was found in 17 cities outside Hubei, China [84].

Hypomagnesemia could represent another factor worsening the prognosis of patients affected with SARSCoV-2 infection. It has been shown a direct correlation between low levels of Magnesium $(\mathrm{Mg})$ and different metabolic disease and persistent chronic inflammation such as hypertension, metabolic syndrome, Type II Diabetes, cardiovascular diseases, osteoporosis and malignant tumors, typically associated with a severe course of COVID-19 disease [85, 86]. Conversely, an oral supplementation of $\mathrm{Mg}$ has been associated with reduced levels of C-reactive protein (PCR) [87]. Therefore, with the ongoing COVID-19 pandemic, oral Mg supplementation could be a potential prevention strategy thanks to its ability to reduce blood pressure and to mediate an antithrombotic effect [88]. As confirmation, the mortality associated with COVID-19 disease is reset in patients with normal $\mathrm{Mg}$ blood levels and its supplementation reduces the need for oxygen therapy and the ICU hospitalization for patients affected with SARS-CoV-2 infection $[89,90]$.

Finally, long-chain omega-3 fatty acids (FAs), the main components of fish oil which include eicosapentaenoic (EPA) and docosahexaenoic (DHA) FAs, are also well known to have beneficial effects on immunity and inflammation. According to Gutierrez et al. omega-3 FAs are incorporated into the cell membrane of neutrophils where they can be metabolized into prostaglandins, 
leukotrienes, thromboxanes, maresins, protectins, and resolvins which then modulate neutrophil migration, phagocytic capacity, as well as the production of reactive oxygen species and cytokines. Moreover, omega-3 FAs improve the function of the macrophages promoting their phagocytic capacity and down-regulate Nuclear Factor-k Beta (NFkB), which in turn reduces inflammatory markers like IL-6, TNF $\alpha$, and tissue growth factorbeta [91]. By reducing the release of proinflammatory mediators through resolvins and other metabolites, EPA and DHA interfere with pulmonary neutrophils recruitment, increase apoptosis by macrophages, and subsequently decrease broncho-alveolar IL- 6 production and as a result, turning off the inflammation of the lung and preventing the cytokine storm. Interestingly, omega-3 FAs also exert anti-viral effects by inducing interferon (IFN) which inhibits viral replication [92]. Based on these considerations, the European Society for Parenteral and Enteral Nutrition supports the use of omega-3 FAs to ameliorate complications of COVID-19, although firm evidence is still missing [93].

In addition to micronutrients, the scientific society has evaluated the potential beneficial effects of several herbals and probiotics in reducing the morbidity and mortality COVID-19 associated [94]. It has been suggested that plants could offer protection against viral infection, through polyphenols, flavonoids and isocyanates such as turmeric, quercetin, resveratrol and, sulforaphane [95, 96]. Based on this evidence, since the beginning of the COVID-19 pandemic, Chinese doctors have proposed the employment of these substances to offer protection against the harmful effects of SARS-CoV-2 virus [97]. By exploiting the inhibitor effect in vitro against MERS virus, resveratrol has been studied also for SARS-CoV-2 infection [98]. It is a polyphenolic compound, chemically known as trans-3,5,4'-trihydroxystilbene, that can be found in red grapes, berries, peanuts, and bamboo [99]. Besides its ability to reduce virus replication, the anti-oxidative and anti-inflammatory effect [100], this polyphenol forms an extremely reliable compound with the human ACE-2 transmitter inhibiting virus interaction with target cells [101]. Furthermore, it is able also to activate SIRT1 and p53 signaling pathways and increase cytotoxic T lymphocytes (CTLs) and natural killer (NK) immune cells [102]. Although there is no indication to use resveratrol to treat SARS-CoV-2 infection, it may be a beneficial adjunctive antiviral agent to consider.

Similar to resveratrol, curcuma (a therapeutic rhizomatous plant of the Zingiberaceae family known as turmeric) can limit the virus's intracellular penetration binding on its surface. Add to this, it reduces the cytokine storm by lowering the NFkB production and, blocking the production of TNF- $\alpha$, it stops the fibrotic degeneration of lung, kidneys, cardiac muscle cells and hematopoietic system cells [103]. Its potential antidepressant and anti-anxiety effect should be not underestimated [104]. Quercetin is a flavonoid that is the most abundant in vegetables and fruits [105]. It acts modulating gene expression of 98/332 human genes (30\%) codifying for cellular receptor proteins for SARS-CoV-2 virus [106]. Abian et al analyzing a small chemical library of about 150 compounds, identified the quercetin, a potent inhibitor of SARS-CoV-2 3CLpro $\left(\mathrm{K}_{\mathrm{i}} \sim 7 \mu \mathrm{M}\right)$ [107]. 3CLpro is a potent viral protease necessary for SARS-CoV2 replication. Biophysical techniques and binding to the active site in molecular simulations have allowed to know the exact mechanism with which quercetin interacts with 3CLpro, making it a candidate for COVID-19 therapeutic treatment. In this regard, it is underway a randomized, open-labeled, and controlled study aimed to investigate the adjuvant benefits of quercetin phytosomes in community-based subjects with confirmed SARS-CoV-2 infection (by RT-PCR). The study has two arms: in the first arm, there are subjects receiving standard COVID19 care per the hospital/physician guidelines, whereas in the other, the subjects are treated with routine COVID19 care and quercetin phytosomes. It is proposed that quercetin phytosomes, after 30 days of supplementation, will boost the natural immunity of the subjects and help to prevent the COVID-19 disease progression, reducing the need for hospitalization [108]. Finally, sulforaphane, a natural activator of nuclear factor erythroid-2-related factor $2(\mathrm{Nrf2})$ and the most powerful human antioxidant, has been suggested as preventive strategy for severe COVID-19. In fact, SARS-CoV-2 virus determines ACE2 destruction after being linked to it, resulting in angiotensin II receptor type 1 (AT1-R) activation with consequent oxidative stress, insulin resistance and endothelial lung damage [109]. The first observations derived from the finding of a low mortality in East Asia, central Europe and Balkans, where there is a high consumption of fermented foods and cabbage, rich in sulforaphane [110]. Therefore, his assumption through cabbage and broccoli could offer protection against the severe forms of disease.

Over the last decades the scientific interest has been focused on understanding the effective role of probiotics as a preventive and therapeutical measure for respiratory infections, including COVID-19 disease [111, 112]. Probiotics, such as Lactobacillus and Bifidobacterium bacteria, are nonpathogenic living microorganisms, typically present in fermented food. Several studies have observed a reduction of viral infections and a mild course of the disease in patients treated with them [113]. In addition, they have also been successfully used both for the treatment and the prevention of gastrointestinal illnesses and inflammatory processes of allergic nature $[114,115]$. 
Regarding COVID-19, experiences with other viral infections, such as influenza, rhinovirus, and respiratory syncytial virus, have shown some beneficial effects shaped to conclude that probiotic supplementation can be useful for the prevention of SARS-CoV-2 infection [116]. As the infectious agent is transmitted also through feces, particularly in children, the administration of probiotics could interfere with this mechanism reinforcing the gut epithelial barrier and directly competing with the proliferation of SARS-CoV-2 [117].

Furthermore, it seems that in patients treated with probiotics there is a reduction of viral transmission due to the enhanced local and systemic immune response and the creation of a "gut-lung axis" which finally favors the clearance of the infectious agent and consequently reduced contagiousness [118].

Although there is no specific evidence on the strain of probiotics to be used, the posology and the duration of the intervention, especially in children, most of the studies on the prevention of pediatric respiratory infections are focused on the effects of Lactobacillus strains and Bifidobacterium strains (or mixtures of strains), usually administered for 3 to 12 months [119].

Nevertheless, further studies are needed to better define their potential use as an adjuvant therapy against viral infections, including SARS-CoV-2.

\section{Mental health and sleep disturbances}

Prolonged quarantine, fear of infection, frustration and boredom, the lack of contact with classmates and teachers and the lack of space at home are just some of the factors that are causing psychological repercussions in children and adolescents during the pandemic [120].

COVID-19 related quarantine implied monotony, stress, impatience, annoyance and varied neuropsychiatric manifestations. In this regard, the 2020 National Report on medicines use in Italy, prepared by the Italian Medicines Agency (AIFA) and the Medicines Utilization Monitoring Centre (OsMed), documented an increase of $11.6 \%$ in using of psychiatric drugs in the pediatric population compared to the previous year. Particularly, antipsychotics are the drugs that recorded the greatest increase in prescriptions $(+17.2 \%)$ followed by antidepressants and medications used for Attention deficit-hyperactivity disorder (ADHD) such as methylphenidate and atomoxetine [121].

In a survey among 8079 Chinese adolescents aged 12-18, Zhou et al. reported a high prevalence of symptoms of depression (43\%), anxiety (37\%) and mixed anxiety and depression (31\%) during the COVID-19 outbreak [122]. In this regard, online psychotherapy can help in providing support to patients with anxiety and stress-related disorders spreading online resources such as information about mental health education, videocounseling, telemedicine and telepsychiatry services. In particular, cognitive-behavioral therapy (CBT) and mindfulness-based cognitive therapy (MCBT) have a strong impact on reducing stress and maladaptive coping behaviors [123].

Sleep disturbances that occurred during SARS-CoV-2 pandemic can also have a major impact on emotional health and immune function. Insufficient sleep increases cardiometabolic disease risk in both children and adolescents and results in anxiety or mood swings, which may be exacerbated by poor mental health during the COVID-19 pandemic [25]. On the other hand, excessive sleep, as documented by Pietrobelli et al. with an increase of $0.65 \mathrm{~h}$ per day during lockdown among Italian children compared to data of 2019, could also alter the circadian system [27]. Additionally, the increase of screen time has a negative influence on sleep balance considering that blue light exposure from device screens near bedtime can suppress melatonin release [124]. Given this association, the American Academy of Pediatrics recommends avoiding screens at least $1 \mathrm{~h}$ before bedtime with specific limits on screen time equal to $1-2 \mathrm{~h}$ per day $[125,126]$.

However, during pandemic, Alves et al., reported an average of $6 \mathrm{~h}$ a day of leisure screen time among children aged from 9 to 15 years [34]. Same results came from Pietrobelli et al. who documented an increase in screen time of 4.85 h per day $(P<0.001)$ [39].

Besides, during social isolation, the intensive use of the internet and social media can spread the practice of the so-called online "challenges" that often lead to self-harm and suicidal intentions in youth [127].

\section{Prevention strategies}

Currently, there is no preventive and curative treatment accepted for SARS-CoV-2 infection. There has been a great effort in seeking drugs able to interfere with viral replication or to stop the progression towards a clinical severe form of the disease, with poor results. In this regard, the WHO research forum on COVID-19 has recently published in 'New England Journal Medicine' data about the use of repurposed antiviral drugs (remdesivir, hydroxychloroquine, lopinavir, and interferon beta1a) for SARS-CoV-2 infection [128]. The study has been conducted in 11,330 adults hospitalized with COVID19 , by engaging 405 hospitals of 30 countries worldwide. Results obtained have not documented any difference in reducing the duration of hospital stay, the need for assisted ventilation and, mortality by comparing patients treated with trial drugs with those treated with standard of care. In the pediatric population data are even less, not allowing the achievement of a universal therapeutic intervention plan. Currently, treatment in children 


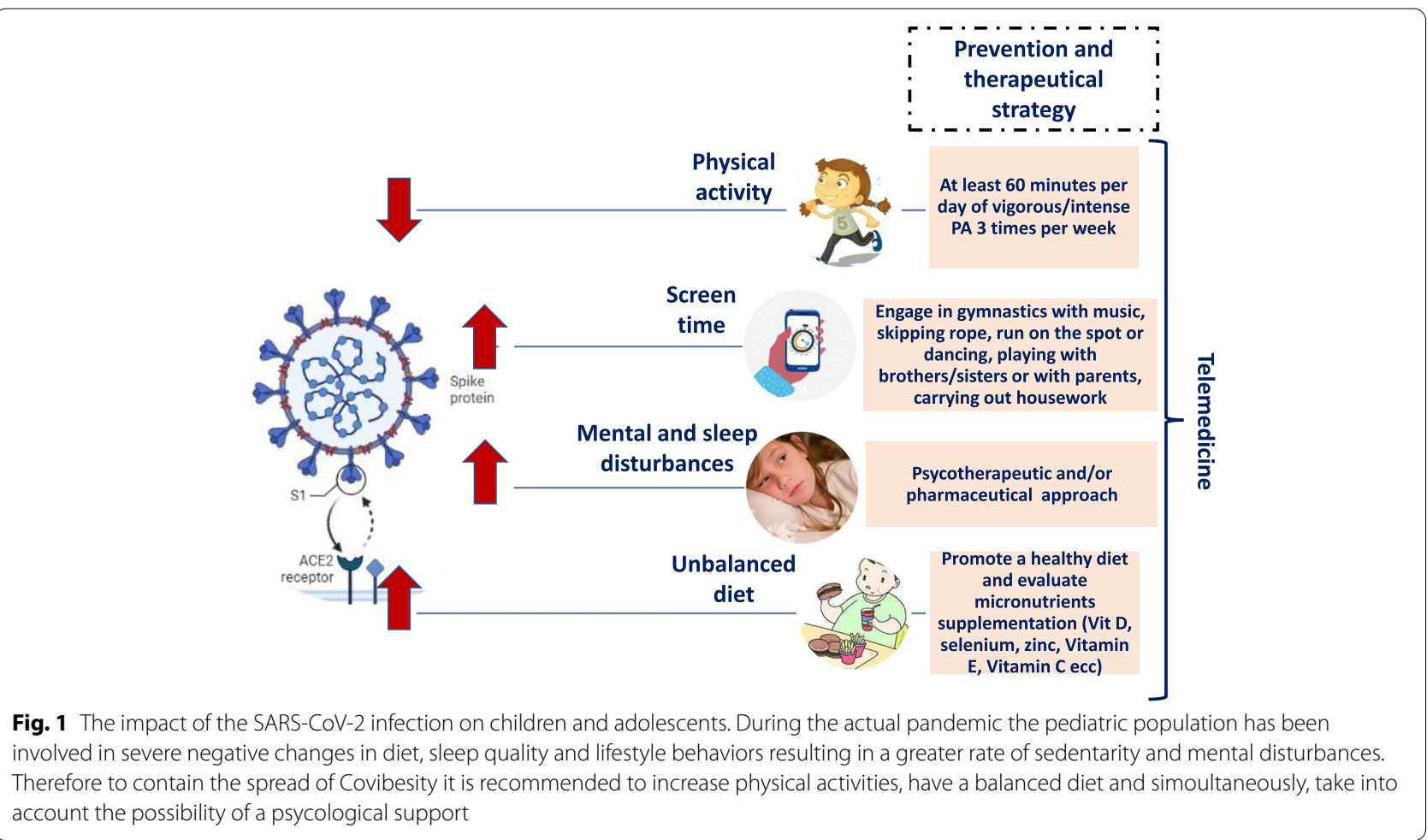

infected with SARS-CoV-2 consists mainly of supportive care, including oxygen and advanced respiratory support, hydration, and antipyretics. Since a relevant viral load, an immune response uncontrolled and pre-existing clinical conditions are physiopathological factors influencing the clinical course of SARS-CoV-2 infection, both control of viral replication and immunomodulation might help to deal with harmful effects of viral infection. Hence the idea to find alternative approaches for new potential treatment strategies [128] Fig. 1.

In this regard, during COVID-19 pandemic a good option to promote more balanced dietary habits and healthy lifestyles is represented by telemedicine, defined by the Institute of Medicine as the use of electronic and telecommunications technologies to provide and support healthcare when distance separates the participants [129]. In fact, the efficacy of computer-based cognitivebehavioral treatments (CCBT) in children and adolescents with anxiety and depression had already been provided by Ebert et al. [130] One of the greater advantages of Internet-based interventions (IMIs) is the possibility to easily include them into the daily activities of the patients. They can help people to overcome the fear of stigmatization by preserving anonymity and allowing individuals to be more aware of their personal progress [131]. Furthermore, Telehealth represents a valid option for treating children with obesity as already confirmed by the decrease in BMI documented by Fleischman et al. after 3 months of primary care provider's visits integrated with telematic assistance [132]. Virtual consultation in the nutrition practice is feasible and encouraged during the COVID-19 pandemic because it has the potential to improve the care provided by practicing registered dietitian nutritionists reducing no-show rates and increasing retention as well as improving health outcomes for patients [133].

Several apps with personalized training features have also emerged offering motivation to people in reinforcing their health by practicing more PA. In conclusion, the pandemic is forcing the health system to find alternatives to face-to-face consultation. In this context, a valid option is represented by telemedicine which allows people to access medical and psychosocial assistance during COVID-19 pandemic in an easier way.

\section{Nutritional approach in the prevention of SARS-CoV-2 infection}

In relation to dietary factors and food habits, WHO has proposed a set of general suggestions such as limiting the consumption of salt, sugar, fat, and alcohol and encouraging the consumption of fiber, water, and fresh products, especially fruits, vegetables, and reduced-fat dairy [134]. Similarly, the Italian National Institute of Health suggests 
healthy and balanced nutrition based on a reduced intake of fats, carbohydrates and sugary drinks. Moreover it suggests, taking advantage of forced quarantine, having a balanced diet for all family members [135].

As previously described, there is a strong relationship between the immune system and nutrition. An adequate nutritional intake is necessary to provide a supply of energy and nutrient for the maintenance and replication of the immune system cells. Simultaneously, the detrimental effect of malnutrition on determining resistance to infections have been described $[49,136]$.

Most of the current therapeutical effort is aimed to inhibit viral replications and to regulate the "cytokine storm", conditions characterized by elevated production of proinflammatory mediators [cytokines Interleukin (IL)-6, tumor necrosis factor (TNF)-alfa, IL-8] [137], resulting from the oxidative stress state related to the virus replications and the consequent general inflammatory state. Moreover, SARS-CoV-2 virus itself may interfere with the equilibrium between NFkB transcription molecules involved in the expression of cytokines and Nrf2 activation, responsible for the expression of antioxidant enzymes [113]. Hence, the need to find therapies able to interfere with this pathophysiological phase of the disease limiting the deleterious effect of SARS-CoV-2 virus on lungs and the rest of the organs.

Lately, there has been a growing interest of the scientific society in nutraceuticals, natural substances with beneficial effects on health. Although it is rare to find them in natural foods in sufficient quantities to obtain these benefits [138], they can be extracted and used as food supplements or additives.

In the pediatric field, the term nutraceutical is used to refer to adequate diet enriched with biologically active elements allowing to obtain health benefits beyond the normal nutritional effects $[139,140]$. Therefore, it is possible to define them as functional foods rich in vitamins, mineral salts, fibers, and fatty acids in such quantities as to positively influence body functions. To date, two classes of nutraceuticals have been described: those that contribute to adequate body growth and those that offer protection against infections [141, 142]. Over time, a lot of nutraceuticals have been proposed. However, the link between the intake of a certain substance, such as vitamins, and the prevention of infections is not always demonstrated, so the possibility to use nutraceuticals to prevent infections, especially respiratory infections, remains questioned. This concept becomes even more important considering the ongoing COVID-19 pandemic. Basic hygienic practices, proper dietary and lifestyle behaviors are necessary to prevent respiratory viral diseases. The meals distribution over the day should provide at least five portions of fruit and vegetables each day and all main meals should contain a balanced proportion of macronutrients to achieve an adequate caloric daily intake [143].

Adequate levels of vitamins and micronutrients are fundamental to improve immune responses as they have antiviral effects and may reduce the severity of symptoms and the duration of respiratory infections. Therefore, an adequate dietary intake of these substances is crucial to ensure the protective effects of the immune system. Fruits, vegetables, meat, fish, poultry and dairy products are the main source of these vitamins and minerals. In particular, vitamin D can be found in anchovies, swordfish, tuna, salmon but also mushrooms and egg yolk. Similarly, fruits (i.e. orange, grapefruit, lime, mandarin, strawberries, kiwi, pineapple), tomato, broccoli, cabbage and spinach, are nourishments rich in vitamin C. Vitamin E instead is found in dried fruits (hazelnut, almonds, peanuts), vegetable oils, green leafy vegetables such as chicory, mango, avocado and fish products like salmon and shrimps. Zinc and selenium can be found in mature cheese, nuts (especially cashews and pecans), both red and white meat and fish products like lobsters, mussels, clams and mullets. Lastly, it should be remembered that fish products, especially salmon, herring, mackerel, sea bass and sea bream are the main source of long-chain omega-3 FAs [59, 144, 145]. In particular, EPA occurs in large quantities in herring, wild sardine and pollock roe whereas in plants it is rather rare; on the other hand, the main sources of DHA are flying fish, herring, pollock and salmon roe [146].

However, considering that for several logistic and financial difficulties it is difficult to maintain a balanced diet during lockdowns or self-quarantine, multi-vitaminmineral (MVM) supplementation for a short period during this COVID-19 pandemic might have a beneficial effect. Indeed, even more attention should be paid to subjects who are malnourished or at risk of malnutrition with the aim to offer them protection against the viral infection and its consequences [147].

Based on the patient's risks factors and baseline 25OHD levels, a daily vitamin D supplementation with 400-1200 UI has been suggested for pediatric patients 154. Therefore, a supplementation within this posology range can reasonably be suggested for the prevention of COVID-19 considering the countless benefits that this would also have in supporting the growth and development of the individual, regardless of the current pandemic [148].

Regarding supplementation with high doses of vitamin $\mathrm{C}$ and $\mathrm{E}$, there is no sufficient evidence about the beneficial effects of such intervention during viral infections, including SARS-CoV-2. Therefore, at the current time, 
vitamin $\mathrm{C}$ and $\mathrm{E}$ supplementation is not strictly recommended [57, 149].

Although less common in pediatric patients, it has been evidenced that $20 \%$ of the general global population, especially elderly patients, or individuals affected by chronic cardiac or pulmonary disease, hypertension and diabetes, have a low zinc intake. Based on these considerations, a daily dose of $10-20 \mathrm{mg}$ of zinc for 6-12 months is reasonable to suggest to help in the prevention of COVID-19 [43, 148]. Similarly, recent studies support selenium supplementation (50 mg/daily) [150]. In Table 1 the suggested posology and the food-sources of nutritional supplements in the prevention of COVID-19 are summarized.

Currently, there is little evidence about the use of nutraceuticals to prevent viral infections. However, considering the non-toxicity of nutraceuticals, they could be used to potentiate immunity. Although different products have been proposed (garlic, oily fish, cranberry juices and broccoli sprouts), it is difficult to find them and for this reason, their use is actually limited [151-153].

In conclusion, it is important a nutrition assessment for patients affected with COVID-19 evaluating the dietary habits and the possible need to receive nutrition support, including vitamin supplementations.

\section{Physical activity promotion}

Based on guidelines issued by the WHO, the Italian National Institute of Health suggested recommended levels of PA for different age groups, including adolescents aged 12-17 years during the COVID-19 outbreak emergency [154]. They propose at least $60 \mathrm{~min}$ per day of vigorous/intense PA 3 times per week including exercises that strengthen muscles and bones. It doesn't matter the place where PA is practiced, even at home, with no special equipment and with limited space. Children and adolescents should engage in gymnastics with music to keep conditional skills trained (strength, endurance, speed) and stimulate cardiovascular and respiratory systems, skipping rope, run on the spot or even some suitable transversal activities like dancing, playing with brothers/ sisters or with parents, carrying out housework (dusting, vacuuming, setting/clearing the table, making their bed) [155].

\section{Vaccination}

The only strategy which allows taking a stop to the SARSCoV-2 spread is vaccination. To September 2021, a total of $671,767,335$ COVID-19 vaccine doses have been distributed by manufacturers to EU/EEA countries of which Comirnaty (BNT162b2), developed by BioNTech/Pfizer, represents $69 \%$ of all doses distributed to EU/EEA countries via the European Commission's Vaccine Strategy, followed by Vaxzevria (AZD1222) (14\%), Spikevax (12\%), and COVID-19 Vaccine Janssen (3\%). Based on data available from 29 countries, $85 \%$ of the doses distributed in the EU/EEA since the beginning of the rollout have been administered.

Scientific data currently available on vaccination for children and adolescents are poor. In fact, it is not yet clear if SARS-CoV-2 vaccine could ensure prolonged immunogenicity or potential adverse effects in children. However, adverse effects have been reported only in 5 out of 1131 vaccinated children, and none of these were related to the study intervention $[156,157]$.

Data on long-term effects are not yet available, and rare age-specific undesirable effects may only emerge with

Table 1 Nutritional supplements in the prevention of COVID-19 disease

\begin{tabular}{|c|c|c|}
\hline Nutritional supplement & Suggested posology & Food sources \\
\hline Vitamin A & $\begin{array}{l}50,000-200,000 \mathrm{IU} \\
\text { every } 4-6 \text { months }\end{array}$ & Cheese, eggs, oil fish, fortified low-fat spreads, milk and yogurt \\
\hline Vitamin C & 100-200 mg/daily & $\begin{array}{l}\text { Fruits (i.e. orange, grapefruit, lime, mandarin, strawberries, kiwi, pineapple), tomato, } \\
\text { broccoli, cabbage and spinach }\end{array}$ \\
\hline Vitamin D & 400-12,000 IU/daily & Anchovies, swordfish, tuna, salmon, mushrooms and egg yolk \\
\hline Vitamin E & 6-11 mg/daily & $\begin{array}{l}\text { Dried fruits (hazelnut, almonds, peanuts), vegetable oils, green leafy vegetables such as } \\
\text { chicory, mango, avocado, and fish products such as salmon and shrimps }\end{array}$ \\
\hline Iron & 7-13 mg/daily ${ }^{a}$ & $\begin{array}{l}\text { Red meat, beans, nuts, dried fruit such as dried apricots, fortified breakfast cereals and } \\
\text { soy bean flour }\end{array}$ \\
\hline Zinc & 10-20 mg/daily & Mature cheese, nuts (especially cashews and pecans), both red and white meat and fish \\
\hline Selenium & $50 \mathrm{mg} /$ daily & products such as lobsters, mussles, clams and mullets \\
\hline Magnesium & 170-250 mg/daily ${ }^{a}$ & $\begin{array}{l}\text { Dark chocolate, avocado, nuts, legumes, tofu, seeds, whole grains, fatty fish (salmon, } \\
\text { mackerel and halibut) and bananas }\end{array}$ \\
\hline Long chain omega-3 fatty acids (FAs) & $100-250 \mathrm{mg} /$ daily $^{\mathrm{a}}$ & Fish especially salmon, herring, mackerel, sea bass and sea bream \\
\hline
\end{tabular}

${ }^{a}$ European Food Safety Authority, available at www.efsa.europe.eu 
increasing vaccination. The only accepted adverse effect is a possible appearance of SARS-CoV-2 myocarditis in vaccinated young patients [158-160], event thought the incidence reported is currently low [161].

Despite the lack of extensive data on the real effectiveness of vaccination against SARS-CoV-2 in children and adolescents, these vaccinations appear to be safe $[156,157]$. Therefore, the main scientific societies are in accord to extend the SARS-CoV-2 vaccine administration also to pediatric patients. Until recently all children over 12 years of age have received vaccination with mRNA vaccines (BioNTech/Pfizer or Moderna). On November 25th EMA's human medicines committee (CHMP) has recommended granting an extension of indication for the COVID-19 vaccine Comirnaty to children aged 5 to 11 after evidence declaring the superiority of benefits over risks in this age group. Starting in December 2021, the consensual approval of the Italian Medicines Agency (AIFA) has allowed the extension of vaccination practice to Italian children aged 5-11 years with a lower dose of Comirnaty that used in people aged 12 and above $(10 \mu \mathrm{g}$ compared with $30 \mu \mathrm{g})$. As in the older age group, it is given as two injections in the muscles of the upper arm, three weeks apart. This is only the first step who will guide towards overcoming the SARS-CoV2 global pandemic.

\section{Conclusions}

The COVID-19 pandemic has a major impact on health and lifestyle behaviors. Children, although less directly affected by the virus, are paying a heavy price through the indirect effects of the crisis, including unbalanced diet leading to an increased risk of both overweight and underweight, sedentary lifestyle, mental health impact and social isolation, addiction to screens and lack of schooling and health care. The COVID-19 quarantine is the only way to prevent virus dissemination, especially in children. However, studies report adverse effects on psychological well-being such as anxiety, worrying, irritability, depressive symptoms, and posttraumatic stress disorder symptoms among children worldwide [162].

Apart from the negative aspects of the current pandemic, facing the consequences of the COVID-19 crisis together with family members could also provide the opportunity to strengthen the sense of community and cohesion inside them promoting social support and resilience. Moreover, among the beneficial consequences of the current crisis, home-schooling could have helped children who have experienced bullying or other stressors during school time. Overcoming the trauma linked to the current pandemic could promote personal growth and psychological development which in turn reinforce self-confidence and become a protective factor for coping with future stressors [163].

As a plan of a comprehensive global intervention, social protection programs, public awareness campaigns and nutrition education programs should not be missing, especially for precarious groups. Pediatricians should actively give prevention information educating their patients and families. At the same time, more attention should be paid to poor families by providing them the economical financial support necessary to guarantee a good quality of life, especially from a nutrition standpoint.

Regarding prevention strategies, scientific attention is focusing on seeking alternative prevention approaches that, beyond the well-known rules aimed at reducing the spread of the virus (masks, social distancing), offer the possibility of preventing damaging effects on the children and adolescents' health. In this regard, the starting point could be a food education intervention aimed to ensure a balanced eating regimen in terms of micro- and macronutrients. Add to this, the use of nutraceuticals, known to be effective in protecting against respiratory viruses, might be a strategical therapeutical approach to prevent SARS-CoV-2 related consequences.

Considering this evidence, although there is no adequate scientific consensus about the possibility to use nutritional support as prevention measure against respiratory infections of children and adolescents [164], the current scientific knowledge should be pushed towards a more careful analysis in this field to get advantages out for the management of COVID-19 pandemic. However, given the relative safety of these substances, their use could still be suggested, especially in children.

The only way to stop the current COVID-19 pandemic is to inhibit the virus spread through vaccination that currently is possible over 12 years of life. Fortunately, further pediatric clinical studies are underway intending to extend the SARS-CoV-2 vaccination to the whole pediatric population.

\section{Authors' contributions}

All the authors have made a substantial, direct, and intellectual contribution to the work. SS and NCR contributed equally to the design and the writing of the work. EV and CF revised it critically. All authors listed approved the work for publication. The authors declare that the research was conducted without any commercial or financial relationships that could be construed as a potential conflict of interest. The authors read and approved the final manuscript.

\section{Declarations}

Competing interests

The authors declare that they have no competing interests. 


\begin{abstract}
Author details
${ }^{1}$ Department of Paediatrics, University of Chieti-Pescara, Chieti, Italy. ${ }^{2}$ Department of Paediatrics, University of Pavia IRCCS San Matteo foundation, Pavia, Italy. ${ }^{3}$ Department of Paediatrics, University of Naples "Federico II", Naples, Italy. ${ }^{4}$ Department of Paediatrics, Children's Hospital "Vittore Buzzi", University of Milan, Milan, Italy.
\end{abstract}

Received: 13 December 2021 Accepted: 11 January 2022

Published online: 04 February 2022

\section{References}

1. Castagnoli R, Votto M, Licari A, et al. Severe acute respiratory syndrome coronavirus 2 (SARS-CoV-2) infection in children and adolescents: a systematic review. JAMA Pediatr. 2020;174(9):882-9. https://doi.org/10. 1001/jamapediatrics.2020.1467.

2. Toba N, Gupta S, Ali AY, et al. COVID-19 under 19: a meta-analysis. Pediatr Pulmonol. 2021;56(6):1332-41. https://doi.org/10.1002/ppul.25312.

3. Grant MC, Geoghegan L, Arbyn M, et al. The prevalence of symptoms in 24,410 adults infected by the novel coronavirus (SARS-CoV-2; COVID-19): a systematic review and meta-analysis of 148 studies from 9 countries. PLoS One. 2020;15(6):e0234765. Published 2020 Jun 23. https://doi.org/10.1371/journal.pone.0234765.

4. Guo T, Shen Q, Guo W, et al. Clinical characteristics of elderly patients with COVID-19 in Hunan Province, China: a multicenter. Retrospective Study Gerontology. 2020;66(5):467-75. https://doi.org/10.1159/00050 8734 .

5. Mehta N, Kalra A, Nowacki AS, et al. Association of use of angiotensinconverting enzyme inhibitors and angiotensin II receptor blockers with testing positive for coronavirus disease 2019 (COVID-19). JAMA Cardiol. 2020;5(9):1020-6. https://doi.org/10.1001/jamacardio.2020.1855.

6. Panahi L, Amiri M, Pouy S. Clinical characteristics of COVID-19 infection in newborns and pediatrics: a systematic review. Arch. Acad Emerg Med. 2020;8(1):e50 Published 2020 Apr 18.

7. "The European Center for Disease Prevention and Control". Available online at: https://www.ecdc.europa.eu/en/interpretation-covid-19data. Accessed 15 Sept 2021.

8. American Academy of Pediatrics. Children and COVID-19: State Data Report. United States of America. (2020) Available online at: https:// downloads.aap.org/AAP/PDF/AAP\%20and\%20CHA\%20-\%20Children\% 20and\%20COVID-19\%20State\%20Data\%20Report\%207.30.20\%20FIN AL.pdf (accessed 2 Oct 2020).

9. Lu X, Zhang L, Du H, Zhang J, Li YY, Qu J, et al. SARS-CoV-2 infection in children. New Engl J Med. 2020;382:1663-5. https://doi.org/10.1056/ NEJMc2005073.

10. Schuez-Havupalo L, Toivonen L, Karppinen S, Kaljonen A, Peltola V. Daycare attendance and respiratory tract infections: a prospective birth cohort study. BMJ Open. 2017;7(9):e014635. Published 2017 Sep 5 https://doi.org/10.1136/bmjopen-2016-014635.

11. Mak PQ, Chung KS, Wong JS, Shek CC, Kwan MY. Anosmia and Ageusia: not an uncommon presentation of COVID-19 infection in children and adolescents. Pediatr Infect Dis J. 2020;39(8):e199-200. https://doi.org/ 10.1097/INF.0000000000002718.

12. 10. Zardini $H$, Soltaninejad H, Ferdosian F, Hamidieh AA, MemarpoorYazdi M. Coronavirus disease 2019 (COVID-19) in children: prevalence, diagnosis, clinical symptoms, and treatment. Int J Gen Med (2020) 13:477-482.doi: https://doi.org/10.2147/IJGM.S262098.

13. Cohen CA, Li APY, Hachim A, et al. SARS-CoV-2 specific T cell responses are lower in children and increase with age and time after infection. Nat Commun. 2021;12(1):4678. Published 2021 Jul 29. https://doi.org/10. 1038/s41467-021-24938-4

14. Palmeira P, Barbuto JAM, Silva CAA, Carneiro-Sampaio M. Why is SARS-CoV-2 infection milder among children? Clinics (Sao Paulo). 2020;75:e1947. https://doi.org/10.6061/clinics/2020/e1947.

15. Parisi GF, Indolfi C, Decimo F, Leonardi S, Miraglia Del Giudice M. COVID19 pneumonia in children: from etiology to management. Front Pediatr. 2020;8:616622. Published 2020 Dec 14. https://doi.org/10.3389/fped. 2020.616622

16. Yonker LM, Neilan AM, Bartsch Y, et al. Pediatric severe acute respiratory syndrome coronavirus 2 (SARS-CoV-2): clinical presentation, infectivity, and immune responses. J Pediatr. Published online. 2020. https://doi. org/10.1016/j.jpeds.2020.08.037.

17. Borrelli M, Corcione A, Castellano F, Fiori Nastro F, Santamaria F. Coronavirus disease 2019 in children. Front Pediatr. 2021;9:668484. Published 2021 May 28. https://doi.org/10.3389/fped.2021.668484.

18. Rostad CA, Kamidani S, Anderson EJ. Implications of SARS-CoV-2 viral load in children: getting Back to school and Normal [published online ahead of print, 2021 Jun 11]. JAMA Pediatr. 2021. https://doi.org/10. 1001/jamapediatrics.2021.2022

19. Horchinbilig U, Gao Y, Chang H, et al. Investigation of 100 SARS-CoV-2 infected families in Wuhan: transmission patterns and follow-up. J Glob Health. 2020;10(2):021103. https://doi.org/10.7189/jogh.10.021103.

20. Galluccio A, Caparello G, Avolio E, et al. Self-perceived physical activity and adherence to the Mediterranean diet in healthy adolescents during COVID-19: findings from the DIMENU pilot study. Healthcare (Basel). 2021;9(6):622. Published 2021 May 23. https://doi.org/10.3390/healt hcare9060622.

21. Dunton GF, Do B, Wang SD. Early effects of the COVID-19 pandemic on physical activity and sedentary behavior in children living in the U.S. BMC Public Health. 2020;20(1):1351. Published 2020 Sep 4. https://doi. org/10.1186/s12889-020-09429-3.

22. Fore HH, Dongyu Q, Beasley DM, Ghebreyesus TA. Child malnutrition and COVID-19: the time to act is now. Lancet. 2020;396(10250):517-8. https://doi.org/10.1016/S0140-6736(20)31648-2.

23. Dunn CG, Kenney E, Fleischhacker SE, Bleich SN. Feeding lowincome children during the Covid-19 pandemic. N Engl J Med. 2020:382(18):e40. https://doi.org/10.1056/NEJMp2005638.

24. Government, I. Nuovo Coronavirus. https://www.salute.gov.it/portale/ nuovocoronavirus/dettaglioFaqNuovoCoronavirus.jsp?lingua=italiano\& $\mathrm{id}=257$ (2021).

25. Bates LC, Zieff G, Stanford K, et al. COVID-19 impact on behaviors across the 24-hour day in children and adolescents: physical activity, sedentary behavior, and sleep. Children (Basel). 2020;7(9):138. Published 2020 Sep 16. https://doi.org/10.3390/children7090138.

26. Zemrani B, Gehri M, Masserey E, Knob C, Pellaton R. A hidden side of the COVID-19 pandemic in children: the double burden of undernutrition and overnutrition. Int J Equity Health. 2021;20(1):44. Published 2021 Jan 22. https://doi.org/10.1186/s12939-021-01390-w.

27. Pietrobelli A, Pecoraro L, Ferruzzi A, et al. Effects of COVID-19 lockdown on lifestyle behaviors in children with obesity living in Verona, Italy: a longitudinal study. Obesity (Silver Spring). 2020;28(8):1382-5. https:// doi.org/10.1002/oby.22861.

28. Di Renzo L, Gualtieri P, Pivari F, et al. Eating habits and lifestyle changes during COVID-19 lockdown: an Italian survey. J Transl Med. 2020;18(1):229. Published 2020 Jun 8. https://doi.org/10.1186/ s12967-020-02399-5.

29. Ruiz-Roso MB, de Carvalho PP, Mantilla-Escalante DC, et al. Covid-19 confinement and changes of Adolescent's dietary trends in Italy, Spain, Chile, Colombia and Brazil. Nutrients. 2020;12(6):1807. Published 2020 Jun 17. https://doi.org/10.3390/nu12061807

30. Kang HM, Jeong DC, Suh BK, Ahn MB. The impact of the coronavirus Disease-2019 pandemic on childhood obesity and vitamin D status. J Korean Med Sci. 2021;36(3):e21. Published 2021 Jan 18. https://doi.org/ 10.3346/jkms.2021.36.e21.

31. Allabadi, H. et al. (2020). Impact of COVID-19 lockdown on dietary and lifestyle behaviours among adolescents in Palestine. DHH, 7(2):https:// journalofhealth.co.nz/?page_id $=2170$

32. Mattioli AV, Sciomer S, Cocchi C, Maffei S, Gallina S. Quarantine during COVID-19 outbreak: changes in diet and physical activity increase the risk of cardiovascular disease. Nutr Metab Cardiovasc Dis. 2020;30(9):1409-17. https://doi.org/10.1016/j.numecd.2020.05.020.

33. Moynihan AB, van Tilburg WA, Igou ER, Wisman A, Donnelly AE, Mulcaire $J B$. Eaten up by boredom: consuming food to escape awareness of the bored self. Front Psychol. 2015:6:369. Published 2015 Apr 1. https://doi. org/10.3389/fpsyg.2015.00369.

34. Tester JM, Rosas LG, Leung CW. Food insecurity and pediatric obesity: a double whammy in the era of COVID-19. Curr Obes Rep. 2020;9(4):44250. https://doi.org/10.1007/s13679-020-00413-x.

35. Moore SA, Faulkner G, Rhodes RE, et al. Impact of the COVID-19 virus outbreak on movement and play behaviours of Canadian children 
and youth: a national survey. Int J Behav Nutr Phys Act. 2020;17(1):85. Published 2020 Jul 6. https://doi.org/10.1186/s12966-020-00987-8.

36. Xiang M, Zhang Z, Kuwahara K. Impact of COVID-19 pandemic on children and adolescents' lifestyle behavior larger than expected. Prog Cardiovasc Dis. 2020;63(4):531-2. https://doi.org/10.1016/j.pcad.2020. 04.013.

37. Laddu DR, Lavie CJ, Phillips SA, Arena R. Physical activity for immunity protection: inoculating populations with healthy living medicine in preparation for the next pandemic. Prog Cardiovasc Dis. 2021;64:102-4. https://doi.org/10.1016/j.pcad.2020.04.006.

38. Korczak DJ, Madigan S, Colasanto M. Children's physical activity and depression: a Meta-analysis. Pediatrics. 2017;139(4):e20162266. https:// doi.org/10.1542/peds.2016-2266.

39. Khan MA, Moverley Smith JE. "Covibesity," a new pandemic. Obes Med. 2020;19:100282. https://doi.org/10.1016/j.obmed.2020.100282.

40. Ribeiro KDDS, Garcia LRS, Dametto JFDS, Assunção DGF, Maciel BLL. COVID-19 and nutrition: the need for initiatives to promote healthy eating and prevent obesity in childhood. Child Obes. 2020;16(4):235-7. https://doi.org/10.1089/chi.2020.0121.

41. Nogueira-de-Almeida CA, Del Ciampo LA, Ferraz IS, Del Ciampo IRL, Contini AA, Ued FDV. COVID-19 and obesity in childhood and adolescence: a clinical review. J Pediatr. 2020;96(5):546-58. https://doi.org/10. 1016/j.jped.2020.07.001.

42. Zachariah P, Johnson CL, Halabi KC, et al. Epidemiology, clinical features, and disease severity in patients with coronavirus disease 2019 (COVID19) in a Children's Hospital in new York City, New York [published correction appears in JAMA Pediatr. 2021 Jun 21;:null]. JAMA Pediatr. 2020;174(10):e202430. https://doi.org/10.1001/jamapediatrics.2020. 2430

43. Yasuhara J, Kuno T, Takagi H, Sumitomo N. Clinical characteristics of COVID-19 in children: a systematic review. Pediatr Pulmonol. 2020;55(10):2565-75. https://doi.org/10.1002/ppul.24991.

44. Cuschieri S, Grech S. COVID-19: a one-way ticket to a global childhood obesity crisis? [published online ahead of print, 2020 Nov 6] J Diabetes Metab Disord. 2020;19(2):1-4. https://doi.org/10.1007/ s40200-020-00682-2.

45. Dooley DG, Bandealy A, Tschudy MM. Low-income children and coronavirus disease 2019 (COVID-19) in the US. JAMA Pediatr. 2020;174(10):922-3. https://doi.org/10.1001/jamapediatrics.2020.20

46. Twomey A, Kiberd B, Matthews T, O'Regan M. Feeding infants - an investment in the future. Ir Med J. 2000;93(8):248-50.

47. Curtis $L J$, Bernier $P$, Jeejeebhoy $K$, et al. Costs of hospital malnutrition. Clin Nutr. 2017;36(5):1391-6. https://doi.org/10.1016/j.clnu.2016.09.009.

48. Rytter MJ, Kolte L, Briend A, Friis H, Christensen VB. The immune system in children with malnutrition--a systematic review. PLoS One. 2014;9(8):e105017. Published 2014 Aug 25. https://doi.org/10.1371/ journal.pone.0105017.

49. Calder PC, Carr AC, Gombart AF, Eggersdorfer M. Optimal nutritional status for a well-functioning immune system is an important factor to protect against viral infections. Nutrients. 2020;12(4):1181. Published 2020 Apr 23. https://doi.org/10.3390/nu12041181.

50. Jamwal S, Gautam A, Elsworth J, Kumar M, Chawla R, Kumar P. An updated insight into the molecular pathogenesis, secondary complications and potential therapeutics of COVID-19 pandemic. Life Sci. 2020;257:118105. https://doi.org/10.1016/j.lfs.2020.118105.

51. Wintergerst ES, Maggini S, Hornig DH. Contribution of selected vitamins and trace elements to immune function. Ann Nutr Metab. 2007:51(4):301-23. https://doi.org/10.1159/000107673.

52. Huang Z, Liu Y, Qi G, Brand D, Zheng SG. Role of vitamin a in the immune system. J Clin Med. 2018;7(9):258. Published 2018 Sep 6. https://doi.org/10.3390/jcm7090258.

53. Siddiqui FQ, Ahmad MM, Kakar F, Akhtar S, Dil AS. The role of vitamin a in enhancing humoral immunity produced by antirabies vaccine. East Mediterr Health J. 2001;7(4-5):799-804.

54. Patel N, Penkert RR, Jones BG, et al. Baseline serum vitamin a and D levels determine benefit of Oral vitamin a\&D supplements to humoral immune responses following pediatric influenza vaccination. Viruses. 2019;11(10):907. Published 2019 Sep 30. https://doi.org/10.3390/v1110 0907.
55. James PT, Ali Z, Armitage AE, et al. The role of nutrition in COVID-19 susceptibility and severity of disease: a systematic review. J Nutr. 2021;151(7):1854-78. https://doi.org/10.1093/jn/nxab059.

56. Carr AC, Maggini S. Vitamin C and immune function. Nutrients. 2017;9(11):1211. Published 2017 Nov 3. https://doi.org/10.3390/nu911 1211.

57. Douglas RM, Chalker EB, Treacy B. Vitamin C for preventing and treating the common cold. Cochrane Database Syst Rev. 2000;(2):CD000980. https://doi.org/10.1002/14651858.CD000980.

58. Bae M, Kim H. Mini-review on the roles of vitamin C, vitamin D, and selenium in the immune system against COVID-19. Molecules. 2020;25(22):5346. Published 2020 Nov 16. https://doi.org/10.3390/ molecules 25225346.

59. Shakoor H, Feehan J, Al Dhaheri AS, et al. Immune-boosting role of vitamins $D, C, E$, zinc, selenium and omega-3 fatty acids: could they help against COVID-19? Maturitas. 2021;143:1-9. https://doi.org/10.1016/j. maturitas.2020.08.003.

60. Jolliffe DA, Griffiths CJ, Martineau AR. Vitamin D in the prevention of acute respiratory infection: systematic review of clinical studies. J Steroid Biochem Mol Biol. 2013;136:321-9. https://doi.org/10.1016/j.jsbmb. 2012.11.017.

61. Lemire JM, Archer DC, Beck L, Spiegelberg HL. Immunosuppressive actions of 1,25-dihydroxyvitamin D3: preferential inhibition of Th1 functions. J Nutr. 1995;125(6 Suppl):1704S-8S. https://doi.org/10.1093/jn/ 125.suppl_6.1704S.

62. Zhang Y, Leung DY, Richers BN, et al. Vitamin D inhibits monocyte/ macrophage proinflammatory cytokine production by targeting MAPK phosphatase-1. J Immunol. 2012;188(5):2127-35. https://doi.org/10. 4049/jimmunol.1102412.

63. Jeffery LE, Burke F, Mura M, et al. 1,25-Dihydroxyvitamin D3 and IL-2 combine to inhibit T cell production of inflammatory cytokines and promote development of regulatory T cells expressing CTLA-4 and FoxP3. J Immunol. 2009;183(9):5458-67. https://doi.org/10.4049/jimmu nol.0803217.

64. Bergman P, Lindh AU, Björkhem-Bergman L, Lindh JD. Vitamin D and respiratory tract infections: a systematic review and Meta-analysis of randomized controlled trials. PLoS One. 2013;8(6):e65835. Published 2013 Jun 19. https://doi.org/10.1371/journal.pone.0065835.

65. Malaguarnera L. Vitamin D3 as potential treatment adjuncts for COVID19. Nutrients. 2020;12(11):3512. Published 2020 Nov 14. https://doi.org/ 10.3390/nu12113512.

66. Martineau AR, Jolliffe DA, Hooper RL, et al. Vitamin D supplementation to prevent acute respiratory tract infections: systematic review and meta-analysis of individual participant data. BMJ. 2017;356:16583. Published 2017 Feb 15. https://doi.org/10.1136/bmj.i6583.

67. Panfili FM, Roversi M, D'Argenio P, Rossi P, Cappa M, Fintini D. Possible role of vitamin D in Covid-19 infection in pediatric population. J Endocrinol Investig. 2021;44(1):27-35. https://doi.org/10.1007/ s40618-020-01327-0.

68. Pereira M, Dantas Damascena A, Galvão Azevedo LM, de Almeida OT, da Mota SJ. Vitamin D deficiency aggravates COVID-19: systematic review and meta-analysis [published online ahead of print, 2020 Nov 4]. Crit Rev Food Sci Nutr. 2020;1-9. https://doi.org/10.1080/10408398.2020. 1841090.

69. YIImaz K, Şen V. Is vitamin D deficiency a risk factor for COVID-19 in children? Pediatr Pulmonol. 2020;55(12):3595-601. https://doi.org/10. 1002/ppul.25106.

70. Beck MA, Williams-Toone D, Levander OA. Coxsackievirus B3-resistant mice become susceptible in se/vitamin E deficiency. Free Radic Biol Med. 2003;34(10):1263-70. https://doi.org/10.1016/s0891-5849(03) 00101-1.

71. Siripanthong B, Nazarian S, Muser D, et al. Recognizing COVID-19-related myocarditis: the possible pathophysiology and proposed guideline for diagnosis and management. Heart Rhythm. 2020;17(9):1463-71. https://doi.org/10.1016/j.hrthm.2020.05.001.

72. Mullick S, Rusia U, Sikka M, Faridi MA. Impact of iron deficiency anaemia on T lymphocytes \& their subsets in children. Indian J Med Res. 2006;124(6):647-54.

73. Attia MA, Essa SA, Nosair NA, Amin AM, El-Agamy OA. Effect of iron deficiency anemia and its treatment on cell mediated immunity. Indian 
J Hematol Blood Transfus. 2009;25(2):70-7. https://doi.org/10.1007/ s12288-009-0017-3.

74. Thorson JA, Smith KM, Gomez F, Naumann PW, Kemp JD. Role of iron in T cell activation: $\mathrm{TH} 1$ clones differ from $\mathrm{TH} 2$ clones in their sensitivity to inhibition of DNA synthesis caused by lgG Mabs against the transferrin receptor and the iron chelator deferoxamine. Cell Immunol. 1991:134(1):126-37. https://doi.org/10.1016/0008-8749(91)90336-a.

75. Drury KE, Schaeffer M, Silverberg Jl. Association between atopic disease and Anemia in US children. JAMA Pediatr. 2016;170(1):29-34. https:// doi.org/10.1001/jamapediatrics.2015.3065.

76. Bédard A, Lewis SJ, Burgess S, Henderson AJ, Shaheen SO. Maternal iron status during pregnancy and respiratory and atopic outcomes in the offspring: a Mendelian randomisation study. BMJ open. Respir Res. 2018;5(1):e000275. Published 2018 Mar 30. https://doi.org/10.1136/ bmjresp-2018-000275.

77. Ward RJ, Crichton RR, Taylor DL, Della Corte L, Srai SK, Dexter DT. Iron and the immune system. J Neural Transm (Vienna). 2011;118(3):315-28. https://doi.org/10.1007/s00702-010-0479-3.

78. Weiss $\mathrm{G}$, Ganz T, Goodnough LT. Anemia of inflammation. Blood. 2019;133(1):40-50. https://doi.org/10.1182/blood-2018-06-856500.

79. Skalny AV, Rink L, Ajsuvakova OP, et al. Zinc and respiratory tract infections: perspectives for COVID-19 (review). Int J Mol Med. 2020;46(1):1726. https://doi.org/10.3892/ijmm.2020.4575.

80. Samad N, Sodunke TE, Abubakar AR, et al. The implications of zinc therapy in combating the COVID-19 global pandemic. J Inflamm Res. 2021;14:527-50. Published 2021 Feb 26. https://doi.org/10.2147/JIR. S295377.

81. Rerksuppaphol S, Rerksuppaphol L. A randomized controlled trial of zinc supplementation in the treatment of acute respiratory tract infection in Thai children. Pediatr Rep. 2019;11 (2):7954. Published 2019 May 23. https://doi.org/10.4081/pr.2019.7954

82. Avery JC, Hoffmann PR, et al. Nutrients. 2018;10(9):1203. Published 2018 Sep 1. https://doi.org/10.3390/nu10091203.

83. Moghaddam A, Heller RA, Sun Q, et al. Selenium Deficiency Is Associated with Mortality Risk from COVID-19. Nutrients. 2020;12(7):2098. Published 2020 Jul 16. https://doi.org/10.3390/nu12072098.

84. Zhang J, Taylor EW, Bennett K, Saad R, Rayman MP. Association between regional selenium status and reported outcome of COVID-19 cases in China. Am J Clin Nutr. 2020;111(6):1297-9. https://doi.org/10.1093/ajcn/ nqaa095.

85. Kumar P, Bhargava S, Agarwal PK, Garg A, Khosla A. Association of serum magnesium with type 2 diabetes mellitus and diabetic retinopathy. J Family Med Prim Care. 2019;8(5):1671-7. https://doi.org/10.4103/ffmpc. jfmpc_83_19.

86. Dai Q, Zhu X, Manson JE, et al. Magnesium status and supplementation influence vitamin D status and metabolism: results from a randomized trial. Am J Clin Nutr. 2018;108(6):1249-58. https://doi.org/10.1093/ajcn/ nqy 274.

87. Shechter M, Merz CN, Paul-Labrador M, et al. Oral magnesium supplementation inhibits platelet-dependent thrombosis in patients with coronary artery disease. Am J Cardiol. 1999;84(2):152-6. https://doi.org/ 10.1016/s0002-9149(99)00225-8.

88. Micke O, Vormann J, Kisters K. Magnesium and COVID-19 - Some Further Comments - A Commentary on Wallace TC. Combating COVID19 and Building Immune Resilience: A Potential Role for Magnesium Nutrition? J Am Coll Nutr. 2020;1-9. doi:https://doi.org/10.1080/07315 724.2020.1785971. Cited in: PMID: 32649272 [published online ahead of print, 2020 Oct 16]. J Am Coll Nutr. 2020;1-3. doi:https://doi.org/10. 1080/07315724.2020.1816230

89. Alamdari NM, Afaghi S, Rahimi FS, et al. Mortality risk factors among hospitalized COVID-19 patients in a major referral Center in Iran. Tohoku J Exp Med. 2020;252(1):73-84. https://doi.org/10.1620/tjem.252.73.

90. Tan CW, Ho LP, Kalimuddin S, et al. Cohort study to evaluate the effect of vitamin $D$, magnesium, and vitamin $B_{12}$ in combination on progression to severe outcomes in older patients with coronavirus (COVID19). Nutrition. 2020;79-80:111017. https://doi.org/10.1016/j.nut.2020. 111017.

91. Gutiérrez S, Svahn SL, Johansson ME. Effects of Omega-3 fatty acids on immune cells. Int J Mol Sci. 2019;20(20):5028. Published 2019 Oct 11. https://doi.org/10.3390/ijms20205028.
92. Hathaway D, Pandav K, Patel M, et al. Omega 3 fatty acids and COVID19: a comprehensive review. Infect Chemother. 2020;52(4):478-95. https://doi.org/10.3947/ic.2020.52.4.478.

93. Barazzoni R, Bischoff SC, Breda J, et al. ESPEN expert statements and practical guidance for nutritional management of individuals with SARS-CoV-2 infection. Clin Nutr. 2020;39(6):1631-8. https://doi.org/10. 1016/..cInu.2020.03.022.

94. Mousa HA. Prevention and treatment of influenza, influenza-like illness, and common cold by herbal, complementary, and natural therapies. J Evid Based Complementary Altern Med. 2017;22(1):166-74. https://doi. org/10.1177/2156587216641831.

95. Calil IP, Fontes EPB. Plant immunity against viruses: antiviral immune receptors in focus. Ann Bot. 2017;119(5):711-23. https://doi.org/10. 1093/aob/mcw200.

96. Catel-Ferreira M, Tnani H, Hellio C, Cosette P, Lebrun L. Antiviral effects of polyphenols: development of bio-based cleaning wipes and filters. J Virol Methods. 2015;212:1-7. https://doi.org/10.1016/j.jviromet.2014.10. 008 .

97. Zhang L, Liu Y. Potential interventions for novel coronavirus in China: a systematic review. J Med Virol. 2020;92(5):479-90. https://doi.org/10. 1002/jmv.25707.

98. Lin SC, Ho CT, Chuo WH, Li S, Wang TT, Lin CC. Effective inhibition of MERS-CoV infection by resveratrol. BMC Infect Dis. 2017;17(1):144. Published 2017 Feb 13. https://doi.org/10.1186/s12879-017-2253-8,

99. Bonechi C, Martini S, Magnani A, Rossi C. Stacking interaction study of trans-resveratrol (trans-3,5,4'-trihydroxystilbene) in solution by nuclear magnetic resonance and Fourier transform infrared spectroscopy. Magn Reson Chem. 2008;46(7):625-9. https://doi.org/10.1002/mrc. 2217.

100. Filardo S, Di Pietro M, Mastromarino P, Sessa R. Therapeutic potential of resveratrol against emerging respiratory viral infections. Pharmacol Ther. 2020;214:107613. https://doi.org/10.1016/j.pharmthera.2020. 107613.

101. Horne JR, VohI MC. Biological plausibility for interactions between dietary fat, resveratrol, ACE2, and SARS-CoV illness severity. Am J Physiol Endocrinol Metab. 2020;318(5):E830-3. https://doi.org/10.1152/ajpen do.00150.2020.

102. Ramdani LH, Bachari K. Potential therapeutic effects of resveratrol against SARS-CoV-2. Acta Virol. 2020;64(3):276-80. https://doi.org/10. 4149/av_2020_309.

103. Soni VK, Mehta A, Ratre YK, et al. Curcumin, a traditional spice component, can hold the promise against COVID-19? Eur J Pharmacol. 2020;886:173551. https://doi.org/10.1016/j.ejphar.2020.173551.

104. Soni VK, Mehta A, Shukla D, Kumar S, Vishvakarma NK. Fight COVID-19 depression with immunity booster: curcumin for psychoneuroimmunomodulation. Asian J Psychiatr. 2020;53:102378. https://doi.org/10. 1016/j.ajp.2020.102378.

105. Zhou A, Sadik OA. Comparative analysis of quercetin oxidation by electrochemical, enzymatic, autoxidation, and free radical generation techniques: a mechanistic study. J Agric Food Chem. 2008;56(24):12081-91. https://doi.org/10.1021/jf802413v.

106. Glinsky GV. Tripartite combination of candidate pandemic mitigation agents: vitamin D, quercetin, and estradiol manifest properties of medicinal agents for targeted mitigation of the COVID-19 pandemic defined by genomics-guided tracing of SARS-CoV-2 targets in human cells. Biomedicines. 2020;8(5):129. Published 2020 May 21. https://doi. org/10.3390/biomedicines8050129.

107. Abian O, Ortega-Alarcon D, Jimenez-Alesanco A, et al. Structural stability of SARS-COV-2 3CLpro and identification of quercetin as an inhibitor by experimental screening. Int J Biol Macromol. 2020;164:1693-703. https://doi.org/10.1016/j.jibiomac.2020.07.235

108. Di Pierro F, lqtadar S, Khan $A$, et al. Potential clinical benefits of quercetin in the early stage of COVID-19: results of a second, pilot, randomized, controlled and open-label clinical trial. Int J Gen Med. 2021;14:2807-16. Published 2021 Jun 24. https://doi.org/10.2147/JJGM.S318949.

109. Bousquet J, Anto JM, Czarlewski W, et al. Cabbage and fermented vegetables: from death rate heterogeneity in countries to candidates for mitigation strategies of severe COVID-19. Allergy. 2021;76(3):735-50. https://doi.org/10.1111/all.14549. 
110. Cuadrado A, Pajares M, Benito C, et al. Can activation of NRF2 be a strategy against COVID-19? Trends Pharmacol Sci. 2020;41(9):598-610. https://doi.org/10.1016/j.tips.2020.07.003.

111. Parisi GF, Carota G, Castruccio Castracani C, et al. Nutraceuticals in the prevention of viral infections, including COVID-19, among the pediatric population: a review of the literature. Int J Mol Sci. 2021;22(5):2465. Published 2021 Feb 28. https://doi.org/10.3390/ijms22052465.

112. Giannoni E, Baud D, Agri VD, Gibson GR, Reid G. Probiotics and COVID19. Lancet Gastroenterol Hepatol. 2020;5(8):720-1. https://doi.org/10. 1016/S2468-1253(20)30195-3.

113. Jayawardena R, Sooriyaarachchi P, Chourdakis M, Jeewandara C, Ranasinghe $P$. Enhancing immunity in viral infections, with special emphasis on COVID-19: a review. Diabetes Metab Syndr. 2020;14(4):367-82. https://doi.org/10.1016/j.dsx.2020.04.015.

114. Kang YB, Cai Y, Zhang H. Gut microbiota and allergy/asthma: from pathogenesis to new therapeutic strategies. Allergol Immunopathol (Madr). 2017;45(3):305-9. https://doi.org/10.1016/j.aller.2016.08.004.

115. Leonardi S, Parisi G, Papale M, et al. Small airways in children with allergic rhinoconjunctivitis: the potential role of a multicomponent nutraceutical. Acta Biomed. 2020;91(2):350-5. Published 2020 May 11. https://doi.org/10.23750/abm.v91i2.9641.

116. Kumpu $M$, Lehtoranta $L$, Roivainen $M$, et al. The use of the probiotic Lactobacillus rhamnosus GG and viral findings in the nasopharynx of children attending day care. J Med Virol. 2013;85(9):1632-8. https://doi. org/10.1002/jmv.23623.

117. Baud D, Dimopoulou Agri V, Gibson GR, Reid G, Giannoni E. Using probiotics to flatten the curve of coronavirus disease COVID-2019 pandemic. Front Public Health. 2020;8:186. https://doi.org/10.3389/fpubh.2020. 00186.

118. Budden KF, Gellatly SL, Wood DL, Cooper MA, Morrison M, Hugenholtz P, Hansbro PM. Emerging pathogenic links between microbiota and the gutlung axis. Nat Rev Microbiol 2017 15(1):55-63. doi: https://doi.org/ 10.1038/nrmicro.2016.142. Epub 2016 Oct 3. PMID: 27694885.

119. Wakabayashi $H$, Oda H, Yamauchi K, Abe F. Lactoferrin for prevention of common viral infections. J Infect Chemother. 2014;20(11):666-71. https://doi.org/10.1016/j.jiac.2014.08.003 Epub 2014 Aug 30. PMID: 25182867.

120. Guan W, Ni Z, Hu Y, et al. Clinical characteristics of coronavirus disease 2019 in China. N Engl J Med. 2020;58(4):711-2. https://doi.org/10. 1016/j.jemermed.2020.04.004

121. AlFA's Medicines Utilisation Monitoring Centre (OsMed). National Report on medicines use in Italy. (2021).

122. Zhou SJ, Zhang LG, Wang LL, et al. Prevalence and socio-demographic correlates of psychological health problems in Chinese adolescents during the outbreak of COVID-19. Eur Child Adolesc Psychiatry. 2020:29(6):749-58. https://doi.org/10.1007/s00787-020-01541-4

123. Deolmi M, Pisani F. Psychological and psychiatric impact of COVID19 pandemic among children and adolescents. Acta Biomed. 2020;91(4):e2020149. Published 2020 Nov 10. https://doi.org/10.23750/ abm.v91i4.10870.

124. Cho Y, Ryu SH, Lee BR, Kim KH, Lee E, Choi J. Effects of artificial light at night on human health: a literature review of observational and experimental studies applied to exposure assessment. Chronobiol Int. 2015;32(9):1294-310. https://doi.org/10.3109/07420528.2015.1073158 Epub 2015 Sep 16. PMID: 2637532.

125. Hill D, Ameenuddin N, Reid Chassiakos YL, Cross C, Hutchinson J, Levine A, Boyd R, Mendelson R, Moreno M, Swanson WS. Media and young minds. Pediatrics. 2016;138(5):e20162591. https://doi.org/10.1542/peds. 2016-2591.

126. COUNCIL ON COMMUNICATIONS AND MEDIA, Strasburger VC, Hogan MJ, Mulligan DA, Ameenuddin N, Christakis DA, et al. Children, adolescents, and the media. Pediatrics. 2013;132(5):958-61. https://doi.org/10. 1542/peds.2013-2656.

127. Deslandes SF, Coutinho T. The intensive use of the internet by children and adolescents in the context of COVID-19 and the risks for selfinflicted violence. Cien Saude Colet. 2020;25(suppl 1):2479-86. https:// doi.org/10.1590/1413-81232020256.1.11472020.

128. WHO Solidarity Trial Consortium, Pan H, Peto R, et al. Repurposed antiviral drugs for Covid-19 - interim WHO solidarity trial results. N Engl J Med. 2021;384(6):497-511. https://doi.org/10.1056/NEJMoa2023184.
129. Institute of medicine (US) committee on evaluating clinical applications of telemedicine, Field MJ, eds. Telemedicine: a guide to assessing telecommunications in health care. Washington (DC): National Academies Press (US); 1996.

130. Ebert DD, Zarski AC, Christensen $\mathrm{H}$, et al. Internet and computer-based cognitive behavioral therapy for anxiety and depression in youth: a meta-analysis of randomized controlled outcome trials. PLoS One. 2015;10(3):e0119895. Published 2015 Mar 18. https://doi.org/10.1371/ journal.pone.0119895.

131. Domhardt M, Steubl L, Baumeister H. Internet- and Mobile-based interventions for mental and somatic conditions in children and adolescents. Z Kinder Jugendpsychiatr Psychother. 2020;48(1):33-46. https:// doi.org/10.1024/1422-4917/a000625.

132. Fleischman A, Hourigan SE, Lyon HN, et al. Creating an integrated care model for childhood obesity: a randomized pilot study utilizing telehealth in a community primary care setting. Clin Obes. 2016;6(6):380-8. https://doi.org/10.1111/cob.12166.

133. Brunton C, Arensberg MB, Drawert S, Badaracco C, Everett W, McCauley SM. Perspectives of registered dietitian nutritionists on adoption of telehealth for nutrition care during the COVID-19 pandemic. Healthcare (Basel). 2021;9(2):235. Published 2021 Feb 23. https://doi.org/10.3390/ healthcare9020235.

134. WHO, Food and nutrition tips during self-quarantine. Available online at: https://www.euro.who.int/en/health-topics/health-emergencies/

135. Italian National Institute of Health (ISS), Nutrition during the COVID-19 emergency, Available online at: https://www.epicentro.iss.it/en/coron avirus/sars-cov-2-healthy-lifestyles-nutrition

136. Bhaskaram P. Immunobiology of mild micronutrient deficiencies. $\mathrm{Br} \mathrm{J}$ Nutr. 2001;85(Suppl 2):S75-80. https://doi.org/10.1079/bjn2000297.

137. Costela-Ruiz VJ, Illescas-Montes R, Puerta-Puerta JM, Ruiz C, MelguizoRodríguez L. SARS-CoV-2 infection: the role of cytokines in COVID-19 disease. Cytokine Growth Factor Rev. 2020;54:62-75. https://doi.org/10. 1016/j.cytogfr.2020.06.001.

138. Kircheis R, Haasbach E, Lueftenegger D, Heyken WT, Ocker M, Planz $\mathrm{O}$. NF-KB pathway as a potential target for treatment of critical stage COVID-19 patients. Front Immunol. 2020;11:598444. Published 2020 Dec 10. https://doi.org/10.3389/fimmu.2020.598444.

139. Hoffmann PR, Berry MJ. The influence of selenium on immune responses. Mol Nutr Food Res. 2008;52(11):1273-80. https://doi.org/10. 1002/mnfr.200700330.

140. Nasri H, Baradaran A, Shirzad H, Rafieian-Kopaei M. New concepts in nutraceuticals as alternative for pharmaceuticals. Int J Prev Med. 2014;5(12):1487-99.

141. Goncalves-Mendes N, Talvas J, Dualé C, et al. Impact of vitamin D supplementation on influenza vaccine response and immune functions in deficient elderly persons: a randomized placebo-controlled trial. Front Immunol. 2019;10:65. Published 2019 Feb 8. https://doi.org/10.3389/ fimmu.2019.00065.

142. Ginde AA, Blatchford P, Breese K, et al. High-dose monthly vitamin D for prevention of acute respiratory infection in older long-term care residents: a randomized clinical trial. J Am Geriatr Soc. 2017;65(3):496-503. https://doi.org/10.1111/jgs.14679.

143. WHO. Food and nutrition tips during self-quarantine. Europe: Regional office. 2020.

144. Food and Nutrition Research Center (CREA), Available online at: https:// www.crea.gov.it/alimenti-e-nutrizione

145. Food Composition Database for Epidemiological studies published in Italy by the European Institute of Oncology (BDA), Available online at: http://www.bda-ieo.it

146. Cholewski M, Tomczykowa M, Tomczyk M. A comprehensive review of chemistry, sources and bioavailability of Omega-3 fatty acids. Nutrients 2018;10(11):1662. Published 2018 Nov 4. https://doi.org/10.3390/nu101 11662.

147. Bda. COVID-19/coronavirus - advice for the general public. 2020 27/03/2020 29/03/2020]. Available from: https://www.bda.uk.com/ resource/covid-19-corona-virus-advice-for-the-general-public.html.

148. Costagliola G, Spada E, Comberiati P, Peroni DG. Could nutritional supplements act as therapeutic adjuvants in COVID-19? Ital J Pediatr. 2021;47(1):32. https://doi.org/10.1186/s13052-021-00990-0 PMID: 33588905; PMCID: PMC7883952. 
149. Graat JM, Schouten EG, Kok FJ. Effect of daily vitamin E and multivitamin-mineral supplementation on acute respiratory tract infections in elderly persons: a randomized controlled trial. JAMA. 2002;288(6):71521. https://doi.org/10.1001/jama.288.6.715.

150. Broome CS, McArdle F, Kyle JA, et al. An increase in selenium intake improves immune function and poliovirus handling in adults with marginal selenium status. Am J Clin Nutr. 2004;80(1):154-62. https://doi. org/10.1093/ajcn/80.1.154.

151. Müller L, Meyer M, Bauer RN, et al. Effect of Broccoli Sprouts and Live Attenuated Influenza Virus on Peripheral Blood Natural Killer Cells: A Randomized, Double-Blind Study. PLoS One. 2016;11(1):e0147742. Published 2016 Jan 28. doi:https://doi.org/10.1371/journal.pone.01477 42

152. Nabeshima S, Kashiwagi K, Ajisaka K, et al. A randomized, controlled trial comparing traditional herbal medicine and neuraminidase inhibitors in the treatment of seasonal influenza. J Infect Chemother. 2012;18(4):534-43. https://doi.org/10.1007/s10156-012-0378-7.

153. Nantz MP, Rowe CA, Muller C, et al. Consumption of cranberry polyphenols enhances human $\gamma \delta$-T cell proliferation and reduces the number of symptoms associated with colds and influenza: a randomized, placebo-controlled intervention study. Nutr J. 2013;12:161. Published 2013 Dec 13. doi:https://doi.org/10.1186/1475-2891-12-161

154. WHO, Stay physically active during self-quarantine. Available online at: https://www.euro.who.int/en/health-topics/health-emergencies/coron aviruscovid-19/publications-and-technical-guidance/noncommunicable-diseases/stay-physically-active-during-self-quarantine (accessed on 21 May $2021 b$.

155. Italian National Institute of Health (ISS), Let's stay active, also at home!, Available online at: https://www.epicentro.iss.it/en/coronavirus/sarscov-2-healthy-lifestyles-physical-activity

156. CDC. Grading of Recommendations, Assessment, Development, and Evaluation (GRADE): Pfizer-BioNTech COVID-19 Vaccine for Persons Aged 12-15 Years. (2021). Available online at: https://www.cdc.gov/ vaccines/acip/recs/grade/covid-19-pfizer-biontech-vaccine-12-15years.html (accessed 29 2021).

157. Mahase E. Covid-19: Pfizer reports $100 \%$ vaccine efficacy in children aged 12 to 15. BMJ. 2021;373:n881. Published 2021 Apr 1. https://doi. org/10.1136/bmj.n881.

158. Reuters. U.S. CDC Looking Into Heart Inflammation in Some Young Vaccine Recipients. (2021). Available online at: https://www.reuters.com/ business/healthcare-pharmaceuticals/us-cdc-investigating-heart-probl em-fewyoung-vaccine-recipients-nyt-2021-05-22 (accessed 29 June 2021).

159. Reuters. Israel Examining Heart Inflammation Cases in People Who Received Pfizer COVID Shot. (2021). Available online at: https://www. reuters.com/world/middle-east/israel-examining-heart-inflammati oncases-people-who-received-pfizer-covid-shot-2021-04-25 (accessed 29 June 2021).

160. European Medicines Agency. COVID-19 Vaccine Safety Update. 2021. Available online at: https://www.ema.europa.eu/en/news/covid-19 vaccinesupdate-ongoing-evaluation-myocarditis-pericarditis. Accessed 4 July 2021.

161. Centers for Disease Control and Prevention. Myocarditis and Pericarditis Following mRNA COVID-19 Vaccination. 2021. Available online at: https://www.cdc.gov/coronavirus/2019-ncov/vaccines/safety/myoca rditis.html. Accessed 7 July 2021.

162. Marques de Miranda D, da Silva AB, Sena Oliveira AC, Simoes-E-Silva AC How is COVID-19 pandemic impacting mental health of children and adolescents? Int J Disaster Risk Reduct. 2020;51:101845. https://doi.org/ 10.1016/j.ijdrr.2020.101845.

163. Kim JJ, Munroe M, Feng Z, et al. Personal growth and well-being in the time of COVID: an exploratory mixed-methods analysis. Front Psychol. 2021;12:648060. Published 2021 Mar 24. https://doi.org/10.3389/fpsyg. 2021.648060

164. (La prevenzione delle infezioni respiratorie ricorrenti 2020; https://sip.it/ wpcontent/uploads/2020/11/CONSENSUS-IRR-2020-4-3.pdf)

\section{Publisher's Note}

Springer Nature remains neutral with regard to jurisdictional claims in published maps and institutional affiliations.

Ready to submit your research? Choose BMC and benefit from:

- fast, convenient online submission

- thorough peer review by experienced researchers in your field

- rapid publication on acceptance

- support for research data, including large and complex data types

- gold Open Access which fosters wider collaboration and increased citations

- maximum visibility for your research: over $100 \mathrm{M}$ website views per year

At BMC, research is always in progress.

Learn more biomedcentral.com/submissions 